\title{
Developmental expression of GTP-binding proteins in rat testes
}

\author{
S. Lamsam-Casalotti, M. Onoda, V. Papadopoulos and M. Dym* \\ Department of Cell Biology, Georgetown University Medical Center, Washington, DC 20007, USA
}

\begin{abstract}
The expression of guanine nucleotide-binding proteins ( $G$ proteins) during the development of rat testes was investigated. Immunohistochemical studies on frozen sections and isolated testicular cells demonstrated that the expression of the GTP-binding proteins was developmentally regulated and specific for different cell types. The $\alpha$ subunit of the cholera toxinsensitive stimulatory $G$ protein $(G s \alpha)$ was first detected in testes from 7-day-old rats; its value reached a maximum at 23 days and then decreased to very low or undetectable amounts in testes of 45-day-old and adult rats (60-90 days of age). The Gs $\alpha$ subunit appears to be expressed by Sertoli, peritubular myoid and interstitial cells. The common $\beta$ subunit $(\mathrm{G} \beta)$ was present at all ages during development and was more prominent around the periphery of the tubules in younger animals but then became more evident in the cytoplasm of germ cells with increasing age. The pertussis toxin-sensitive inhibitory $G$ proteins, Gi1/2 and Gi3, showed a similar pattern of expression. Sertoli cells and peritubular cells expressed $\mathrm{Gi} 1 / 2$ and $\mathrm{Gi} 3$ at very low levels at all ages, whereas pachytene spermatocytes and round spermatids expressed the inhibitory binding proteins only at later ages of development (45day-old and adult testis). Northern blot analysis showed that with increasing age the Gs $\alpha$ mRNA in the testis decreased and this was confirmed by in situ hybridization. These latter studies showed localization of the transcripts to somatic cells but not to germ cells. Thus, the cellular expression of $G$ proteins is temporally linked to testicular development and this suggests that there is an age-dependent regulation of the effects of hormones and intratesticular factors acting via $G$ protein-linked receptor and effector systems.
\end{abstract}

\section{Introduction}

Guanine nucleotide-binding proteins ( $G$ proteins) are involved in signal transduction, providing a link between membrane receptors and intracellular effectors. Cell surface receptors activated by their specific ligands catalyse GTP-binding by G proteins which then alters enzyme activity resulting in the initiation of membrane effector mechanisms. These effectors include a variety of systems such as adenylyl cyclase, phosphodiesterases and ionic channels (Birnbaumer et al., 1989, 1990).

The peptide hormones FSH and LH play an important role in the development of the testes and in the regulation of spermatogenesis (Means et al., 1980; Platts et al., 1988). FSH acts on Sertoli cells by binding to its cell-surface receptor which is coupled to the stimulatory $G$ protein $(G s \alpha)$ and thus activates adenylyl cyclase to catalyse the production of cAMP, the second messenger (Casey and Gilman, 1988). Other enzymes, namely phospholipase $C$ and $A_{2}$, which may also be regulated by $G$ proteins, have been shown to be involved in Sertoli cell function (Cockcroft and Gomperts, 1985; Jelsema and Axelrod, 1987). Sertoli cells provide the cytoarchitectural support for the developing germ cells and are responsible for their metabolic needs (Parvinen et al., 1986). This cell-cell interaction between Sertoli cells and germ cells is an essential feature of spermatogenesis. Germ cells appear to lack hormone-sensitive adenylyl

${ }^{*}$ Correspondence.

Received 29 December 1992 cyclase (Hildebrandt et al., 1985), although a soluble $\mathrm{Mn}^{2+}$. dependent hormone-insensitive adenylyl cyclase activity has been observed in round spermatids (Gordeladze et al., 1981). However, a $0.9 \mathrm{~kb}$ mRNA species hybridizing to a Gs $\alpha$ probe has been reported in rat haploid germ cells (Haugen et al., 1990).

Using immunohistochemistry, we have previously shown that the $\alpha$ and $\beta$ subunits of the stimulatory G protein are present in 10-day-old rat testis (Dym et al., 1991). The presence of both pertussis and cholera toxin-sensitive GTP-binding proteins in isolated testicular cells has also been reported (Paulssen et al., 1991). In this study, we sought to investigate further the expression of $G$ proteins at the cellular level and to determine their distribution during development using immunocytochemical and in situ hybridization procedures.

\section{Materials and Methods}

\section{Tissues}

Sprague-Dawley rats at different ages $(1,7,12,23,45,60,80$ and 90 days) were killed using $\mathrm{CO}_{2}$ asphyxiation. The testes were then removed, frozen in liquid nitrogen, and used for cryostat sectioning, RNA preparation, or for membrane preparation.

\section{Isolation and culture of testicular cells}

Sertoli and myoid cells were isolated from testes of 15-dayold rats as described by Hadley et al. (1985). Sertoli cells were 


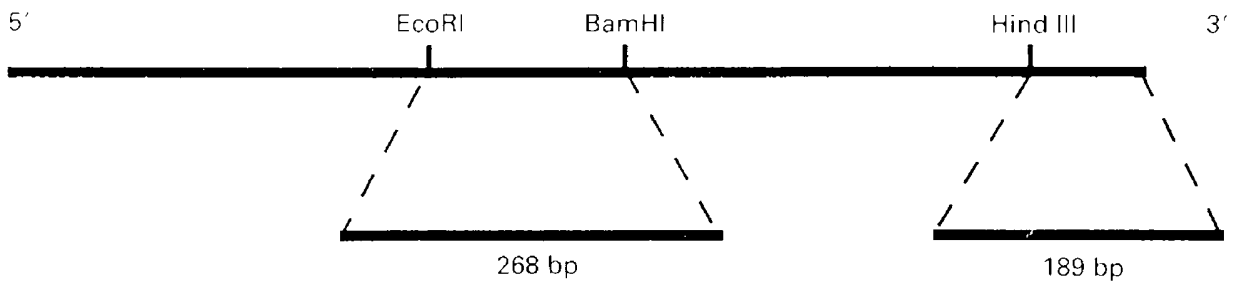

Fig. 1. The restriction sifes of the two cDNA fragments 208 and 189 bpi generated from the original full-length Gsa cDNA subcloned and used as templates for transcription of riboprobes, are shown.

\section{Day 1}

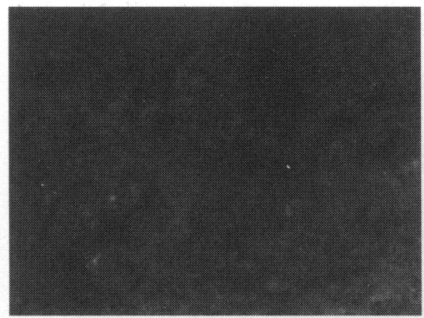

$\mathrm{G} s \alpha$

$\mathrm{G} \beta$
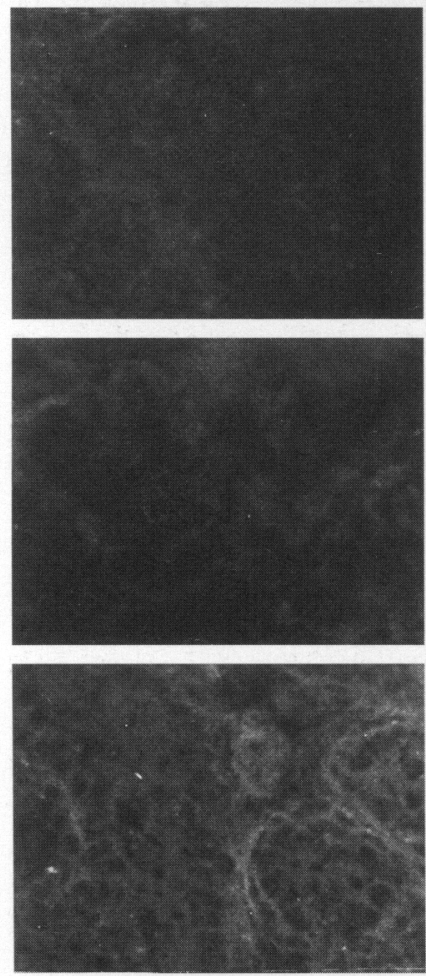

$\mathrm{Gi} 1 / 2$

Gi3

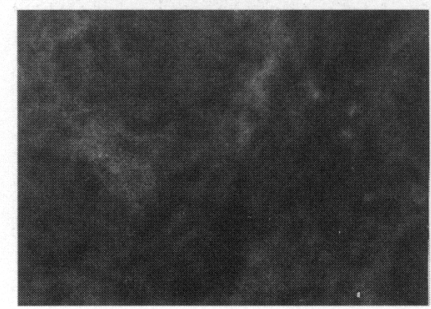

Day 7
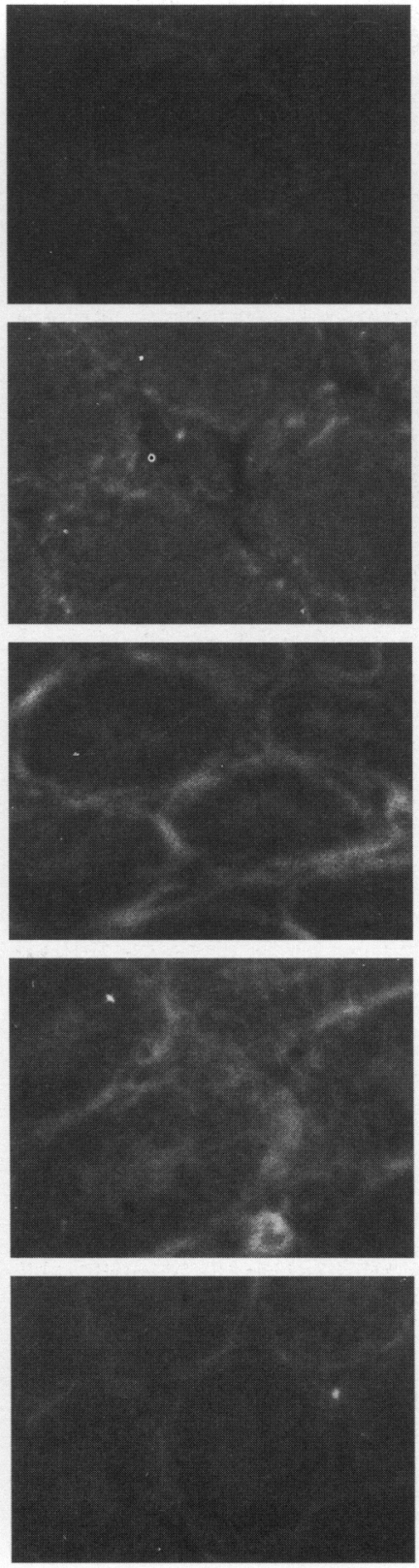

Day 12
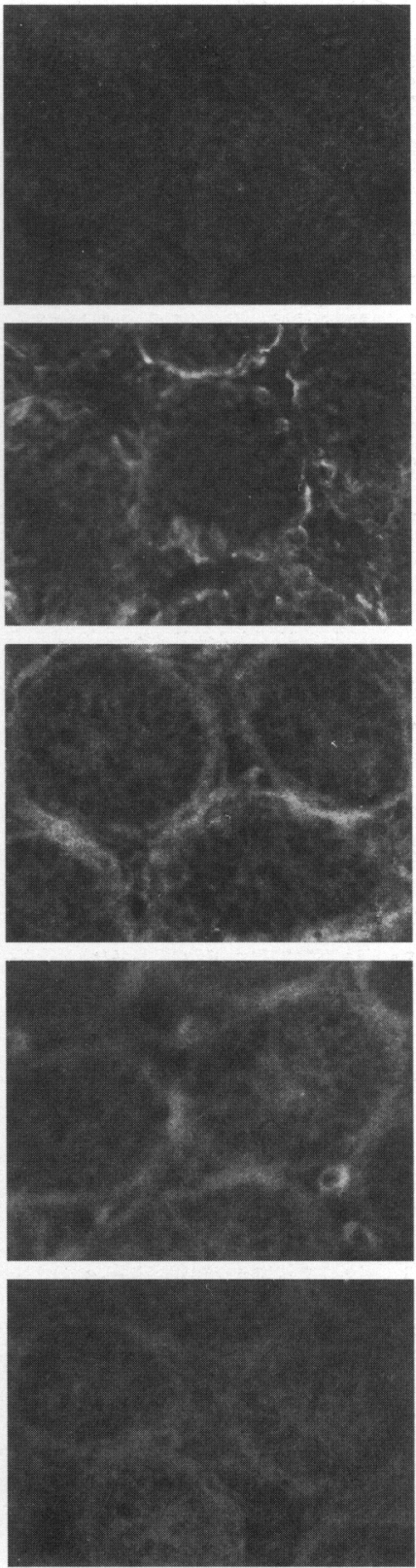

Fig. 2. Immunocytochemical localization of different G proteins (Gsa, G $\beta$, Gi1/2, G,3) at the indicated developmental ages of rat testis. Frozen sections $(10 \mu \mathrm{m}$ were cut thaw mounted on glass stides, and fixed in cold methanol. Incubation with antibodies directed against the indicated G proteins was performed using methods of Dym of al. (1996). NRS: normal rabbit serum. 
placed onto coverslips in serum-free defined medium (SFDM Dulbecco's minimum essential medium (DMEM) containing $100 \mathrm{U}$ penicillin $\mathrm{ml}^{-1}$, $100 \mu \mathrm{g}$ streptomycin $\mathrm{ml}^{-1}, 2 \mu \mathrm{g}$ insulin $\mathrm{ml}^{-1}$, $10 \mathrm{ng}$ epidermal growth factor $\mathrm{ml}^{-1}, 5 \mu \mathrm{g}$ human transferrin $\mathrm{ml}$, $50 \mathrm{ng}$ vitamin $\mathrm{A} \mathrm{ml}^{-1}$, $200 \mathrm{ng}$ vitamin $\mathrm{E} \mathrm{ml}$ ', 10 mmol hydrocortisone $\mathrm{l}^{-1}, 100$ pmol testosterone $\mathrm{I}^{-1}, 10 \mathrm{pmol}$ oestradiol 1 ', 2 mmol glutamine $1^{-1}, 5 \mathrm{ng}$ sodium selenate $\mathrm{ml}$ ', 1 mmol sodium pyruvate $\mathrm{l}^{-1}$, and $22 \mathrm{mmol}$ sodium lactate $\left.\mathrm{I}^{-1}\right)$. Myoid cells were plated on coverslips in $10 \%$ fetal bovine serum. DMEM was purchased from Gibco BRL (Gaithersburg, $\mathrm{MD})$; all other chemicals were obtained from Sigma Chemical Co. (St Louis, MO). The cells were cultured for 3 days before use for the immunocytochemical studies. The myoid cell population was generally a homogeneous population and was not contaminated by other cell types; the Sertoli cell cultures were contaminated with approximately $2 \%$ myoid cells.

Pachytene spermatocytes and round spermatids were isolated from testes of 90-day-old Sprague-Dawley rats by the
Day 23
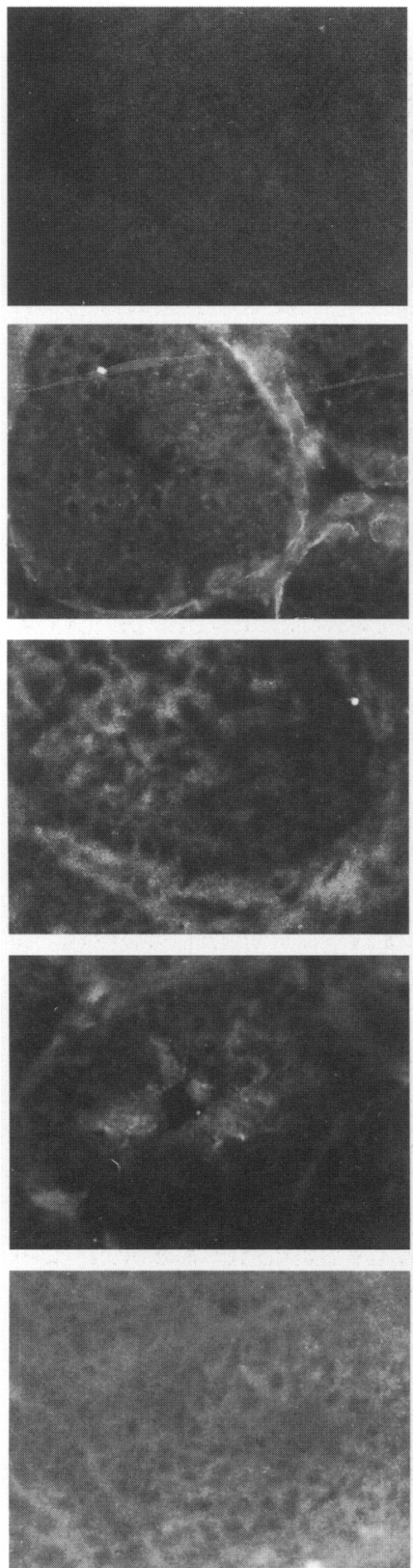

Day 45
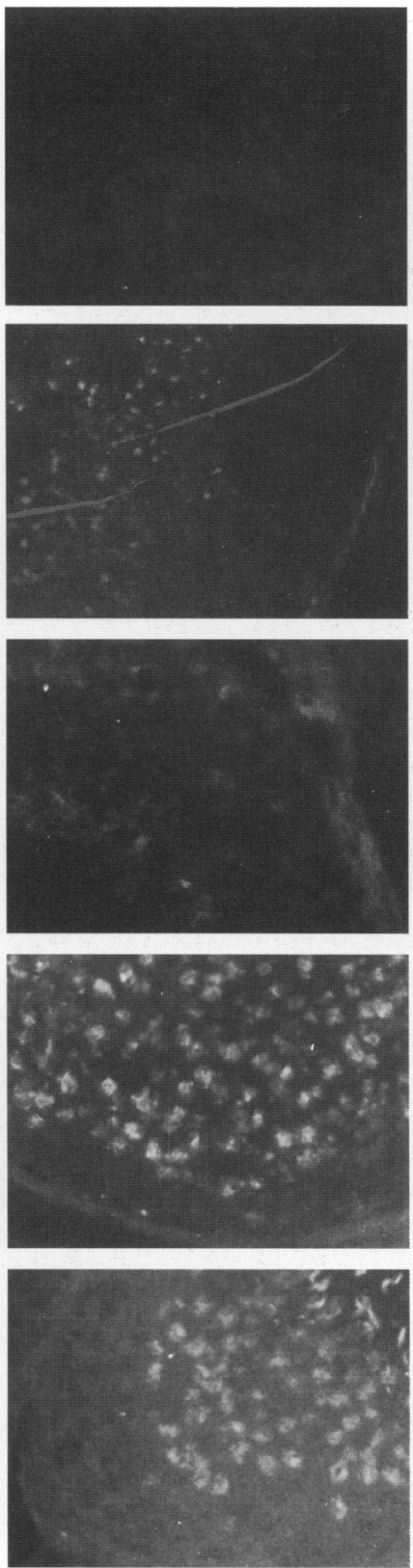

Fig. 2. (contd).
Adult

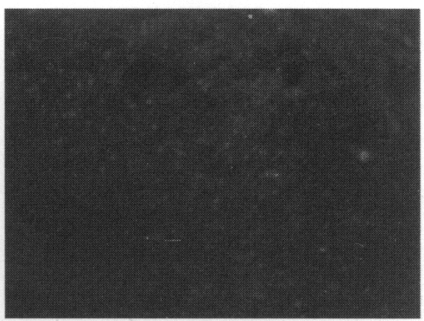

NRS

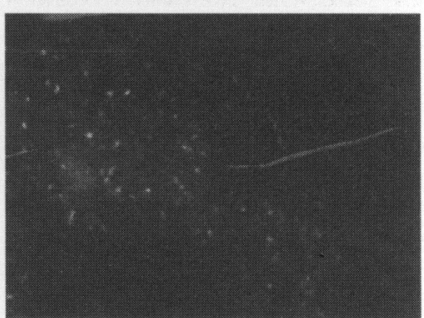

$\mathrm{Gs} \alpha$

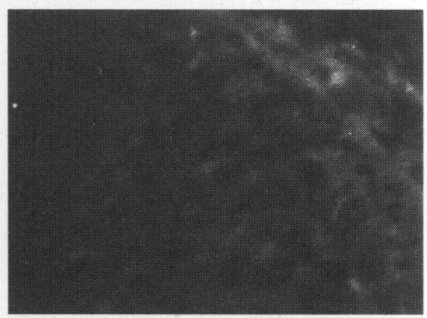

$\mathrm{G} \beta$
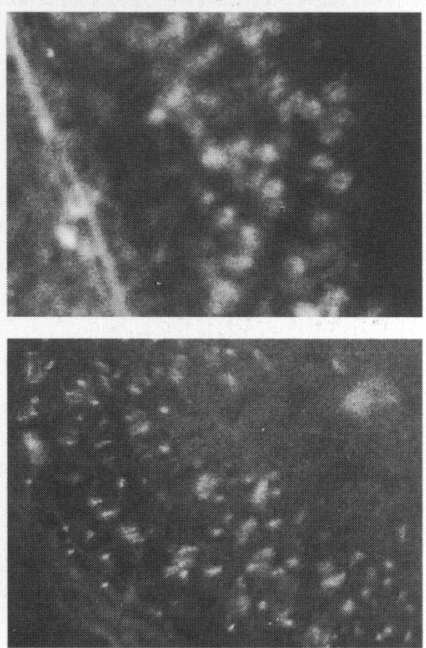

$\mathrm{Gi} 1 / 2$

Gi3 


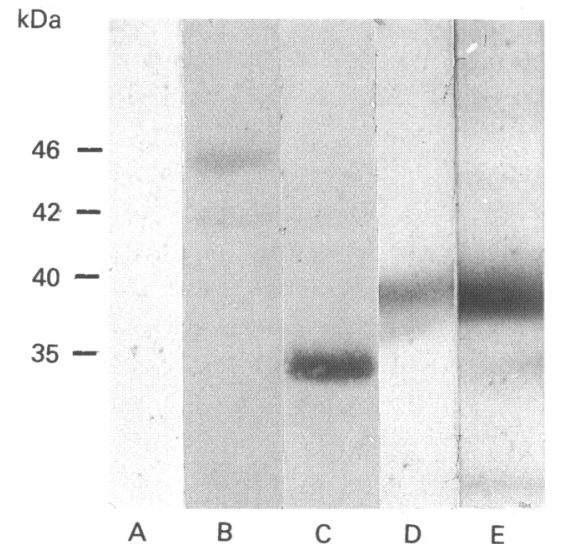

Fig. 3. Immunoblot analysis of (B) Gsa, (C) GB, (D) Gi1/2 and (E) $\mathrm{Gi} 3$ proteins in membranes of testes of 12 -day-old rats. Immunoblot analysis was performed using specific rabbit anti-G-protein antisera or normal rabbit serum (A). Membrane preparations were resolved on $10 \%$ SDS-PAGE gels and then the proteins were transferred to nitrocellulose membranes and incubated with the antibodies for $2 \mathrm{~h}$

method described by Onoda and Djakiew (1991) and used immediately for immunohistostaining. We generally obtained $>95 \%$ purity in the spermatid fraction and $85 \%$ purity in the pachytene spermatocyte fraction.

\section{Antibodies}

Rabbit anti-G-protein antisera (Gs $\alpha, \mathrm{G} \beta, \mathrm{Gi1} / 2$, and $\mathrm{Gi3}$ ) were purchased from Dupont/NEN (Boston, MA). Fluoresceinconjugated and peroxidase-conjugated goat anti-rabbit antibodies were obtained from ICN Immunobiologicals (Lisle, IL).

\section{RNA probes}

Rat olfactory Gs $\alpha$ full length cDNA was a gift from R. R. Reed (Johns Hopkins University, School of Medicine, Baltimore, MD) (Jones and Reed, 1987). Two fragments of the original cDNA were subcloned into pGEM vectors (Promega Biotec., Madison, WI) and used as templates for the transcription of riboprobes complementary (antisense) and noncomplementary (sense) to mRNA (Fig. 1). Riboprobes were synthesized in the presence of ${ }^{35}[\mathrm{~S}]$ CTP to a specific activity of $10^{8}$ c.p.m. $\mu \mathrm{g}^{-1}$.

\section{Membrane preparation}

Testicular membranes were obtained from testes of 12- and 90 -day-old rats by the method previously described by Dym et al. (1991).

\section{Immunohistochemistry}

Immunohistochemistry was performed essentially as described by Dym et al. (1991). Alterations to the protocol included longer washing times after antibody incubations and a 1:3000 dilution of the fluorescein-conjugated goat anti-rabbit antibody.

\section{Immunoblot analysis}

Membrane preparations from testes of 12-day-old and adult (60-90-day-old) rats were resolved on a $10 \%$ SDS-PAGE gel (Laemmli, 1970). Separated proteins were then electrophoretically transferred to nitrocellulose membranes $(0.45 \mu \mathrm{m}$; Hoefer Scientific, San Francisco, CA) and then incubated at $4^{\circ} \mathrm{C}$ overnight in 5\% non-fat milk in PBS to prevent non-specific binding. Primary and peroxidase-conjugated secondary antibodies were diluted at $1: 2000$ and 1:3000, respectively, in 1\% non-fat milk made up in PBS, $0.1 \%(\mathrm{v} / \mathrm{v})$ Triton $\mathrm{X}-100$ and $0.05 \%(v / v)$ Tween 20 . Both primary and secondary antibodies were incubated with the membranes for $2 \mathrm{~h}$ at room temperature and the nitrocellulose strips were washed three times for $10 \mathrm{~min}$ each to remove unbound antibodies. Immunoreactivity was visualized using 3-amino-8-ethyl carbazole as the enzyme substrate.

\section{RNA (northern) analysis}

RNA was isolated from testes of rats of various ages using the method of Chomczynski and Sacchi (1987). The RNA was subjected to electrophoresis and then transferred to a Nytran filter (Schleicher and Schuell, Keene, NH) for hybridization with the antisense and sense strands of the Gs $\alpha$ riboprobe. The filters were prehybridized for $4 \mathrm{~h}$ at $60^{\circ} \mathrm{C}$ in hybridization solution containing $50 \%$ formamide, $5 \times$ SSPE $(20 \times$ SSPE $=174 \mathrm{~g}$ of $\mathrm{NaCl}, 27.6 \mathrm{~g}$ of $\mathrm{NaH}_{2} \mathrm{PO}_{4} \cdot \mathrm{H}_{2} \mathrm{O}$ and $7.4 \mathrm{~g}$ EDTA, pH 7.4 in I l), $10 \%$ Denhardt's, $0.1 \mathrm{mg}$ tRNA ml $\mathrm{m}^{-1}$ and $0.2 \%$ SDS. For hybridization, $25 \times 10^{6}$ c.p.m. of probe was added to the filters in $5 \mathrm{ml}$ and allowed to incubate overnight at $60^{\circ} \mathrm{C}$. The filters were then washed twice for $60 \mathrm{~min}$ each time with $0.1 \times$ SSPE, $0.1 \%$ SDS and then dried and exposed to autoradiography with X-ray film (X-Omat AR, Eastman Kodak, Rochester, NY).

\section{In situ hybridization}

Cryostat sections $(7 \mu \mathrm{m})$ were processed for in situ hybridization essentially following the procedures described by Richardson et al. (1991) and Sandberg and Vuorio (1987). Briefly, sections were fixed in $4 \%$ paraformaldehyde-PBS, passed through a graded series of alcohols and then treated with $1 \mu \mathrm{g}$ proteinase $\mathrm{K} \mathrm{ml}^{-1}$ for $5 \mathrm{~min}$. The reaction was stopped by washing with $2 \mathrm{mg}$ glycine $\mathrm{ml}^{-1}$ in PBS and the tissue was then acetylated with $0.1 \mathrm{~mol}$ acetic anhydride $\mathrm{l}^{-1}$ in 0.1 mol triethanolamine buffer $\mathrm{l}^{-1}, \mathrm{pH} 8.0$, to minimize nonspecific binding of the probe. The sections were washed with PBS, dehydrated and air dried.

Treated sections were incubated for $\mathrm{Ih}$ at $55^{\circ} \mathrm{C}$ in prehybridization mix $\left(1.2 \mathrm{~mol} \mathrm{NaCl} \mathrm{l}{ }^{-1}, 20 \mathrm{mmol}\right.$ Tris- $\mathrm{HCl} \mathrm{l}^{-1}$, $\mathrm{pH} 7.5,4 \mathrm{mmol}$ EDTA $\mathrm{I}^{-1}, 2 \times$ Denhardt's solution, $1 \mathrm{mg}$ yeast tRNA $\mathrm{ml}^{-1}$ ) containing $50 \%$ formamide. The probe $\left(3 \times 10^{6}\right.$ c.p.m. $)$ in prehybridization mix containing $10 \%$ dextran sulfate was added to each slide and incubated at $55^{\circ} \mathrm{C}$ overnight. After hybridization, the slides were washed for $1 \mathrm{~h}$ with a high salt solution of $2 \times \mathrm{SSC}(20 \times \mathrm{SSC}=175.3 \mathrm{~g}$ $\mathrm{NaCl}$ and $88.2 \mathrm{~g}$ sodium citrate in $\mathrm{Il}, \mathrm{pH}$ adjusted to 7.0$)$ containing $50 \%$ formamide and $1 \% 2 \beta$-mercaptoethanol, treated for $30 \mathrm{~min}$ at $37^{\circ} \mathrm{C}$ with $20 \mu \mathrm{g}$ RNase $\mathrm{A} \mathrm{ml}^{-1}$, and rewashed twice for $15 \mathrm{~min}$ each time with the high salt solution. This was 


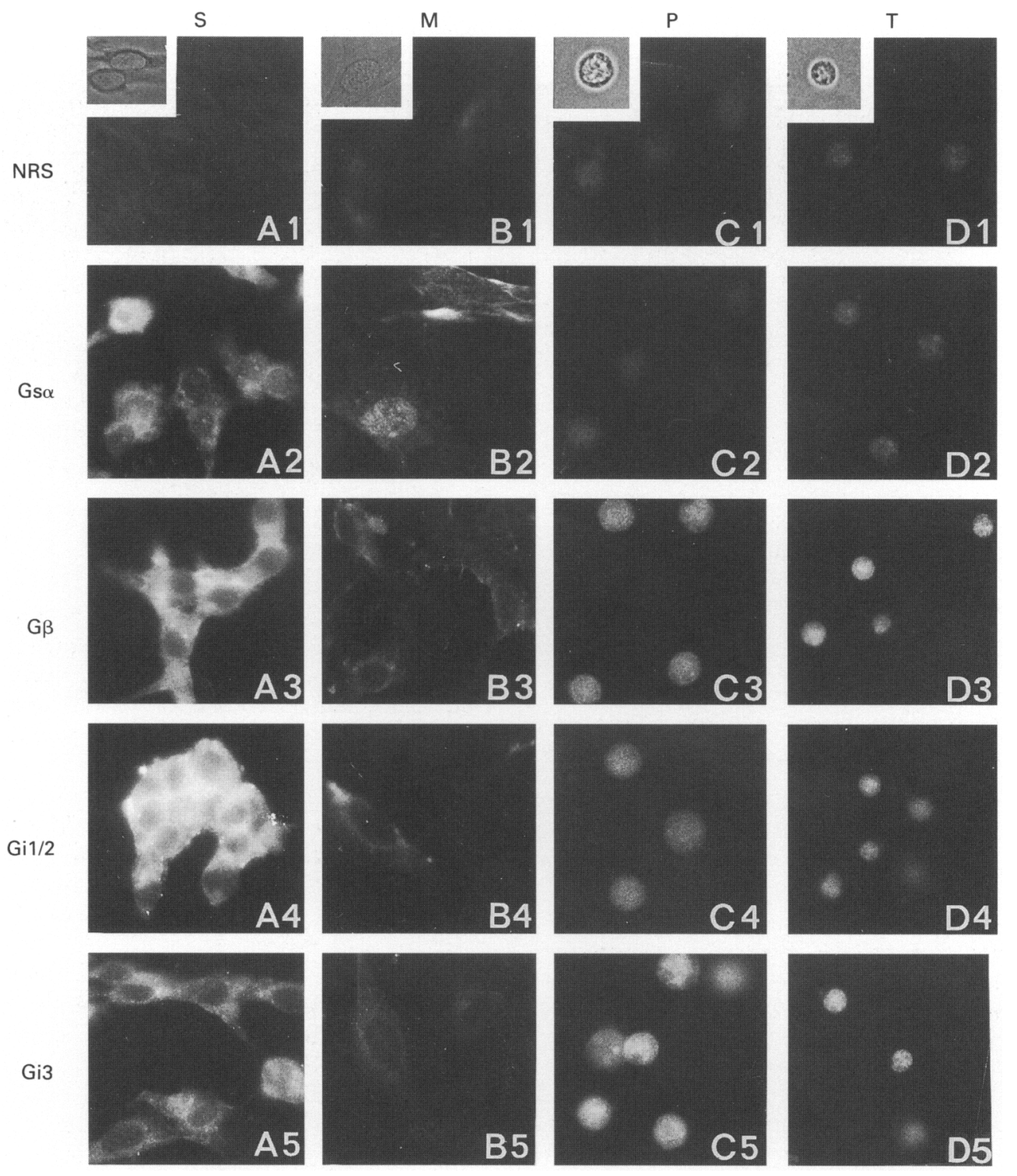

Fig. 4. Immunocytochemical localization of Gs $\alpha, G \beta, G i 1 / 2$, and Gi3 in cultured (S) Sertoli cells and (M) peritubular myoid cells, and in $(P)$ purified preparations of pachytene spermatocytes, and ( $T$ ) round spermatids using specific rabbit anti-G-protein antisera or normal rabbit serum (NRS).

followed by two further washes in more stringent conditions $(0.1 \times$ SSC, $0.5 \% 2 \beta$-mercaptoethanol) and dehydration with alcohol. Autoradiography was performed by dipping the slides in Kodak NTB-2 (Eastman Kodak, Rochester, NY) and exposing them for $4-7$ days at $4 \mathrm{C}$. The slides were developed and then counterstained with haematoxylin.

\section{Results}

Immunocytochemistry and immunoblotting of Gsa in testis

The anti-G protein polyclonal antisera used in these studies were generated in rabbits against the carboxy terminus of the proteins. These antibodies were used to detect the presence of $G$ proteins in different developmental stages of rat testis (Fig. 2). Gs $\alpha$ was not detected in testes of 1-day-old rats, but could be seen in 7-day-old animals and appeared to increase in the 12 day-and 23-day-old animals. The staining was observed mainly at the periphery of the tubules presumably at the basal plasma membranes of Sertoli cells and peritubular cells. Staining was also present in the interstitial tissue of the testis. In 45-day-old and adult (60-90 days of age) rats, the intensity of fluorescence was low (if present at all) and was located at the periphery of the tubules in discrete thin lines. Some nonspecific staining was present in testes of 45-day-old and adult rats that could be attributed to nonspecific antibody binding to the acrosomes of the spermatids, as this was also seen in testes of the same 

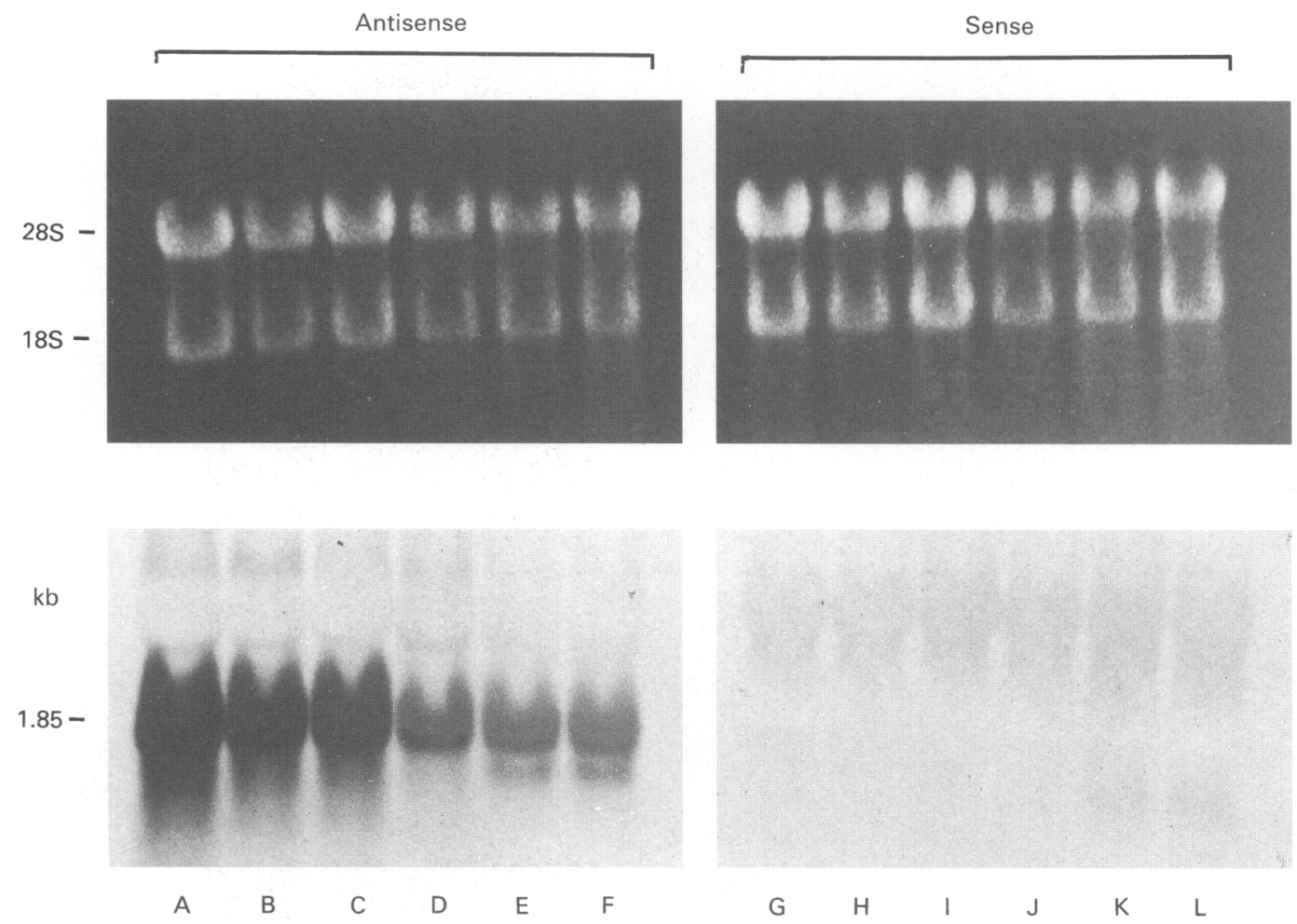

Fig. 5. Northern blot analysis of total RNA of rat testes using antisense and sense probes for the $268 \mathrm{bp}$ fragment of Gsa. Samples were prepared from (A) 1-, (B) 7-, (C) 12-, (D) 23- (E) 45-, and (F) 80-day-old rats. Panels G-L show a lack of hybridization in the sense controls at the same ages. Photographs of the RNA gels, stained with ethidium bromide, are shown in the upper panels.

developmental age stained with normal rabbit sera (see Fig. 2). The anti-G $\beta$ antiserum gave a pattern of staining similar to that of Gs $\alpha$ for testes of 1-, 7- and 12-day-old rats, but in the older animals (23-90 days) staining was also present in the plasma membranes of cells within the seminiferous tubules. The Gi1/2 antiserum stained the testes of all rats investigated, but the pattern of the staining changed from being diffuse peripheral in 1-, 7- and 12-day-old animals to intratubular in testes of 23-dayold rats and intense germ cell staining in testes of 45-day-old and adult rats. Similarly, the Gi3 antiserum intensely stained germ cells in testes of 45-day-old and adult rats, but it was not consistently seen in the younger animals, suggesting a very low expression of the $\mathrm{Gi} 3$ protein.

Immunoblot analyses of testicular plasma membranes obtained from either 12-day-old (Fig. 3) or adult (60-90 days of age) rats (data not shown) indicate that the antisera used in this study recognize proteins of molecular weights identical to those described in other systems (Birnbaumer et al., 1987). The anti$\mathrm{Gs} \alpha$ antiserum recognized two bands of 42 and $46 \mathrm{kDa}$ (Fig. $3 \mathrm{~b}$ ); the anti-G $\beta$ antiserum recognized a $35 \mathrm{kDa}$ protein (Fig. $3 \mathrm{c}$ ); antisera against $\mathrm{Gi} 1 / 2$ and $\mathrm{Gi} 3$ stained proteins of about $40 \mathrm{kDa}$ (Fig. 3d and e, respectively).

To examine further the presence of $G$ proteins in testicular cells, we isolated Sertoli cells and peritubular myoid cells from 15-day-old rats and pachytene spermatocytes and round spermatids from 90-day-old rats and stained them with the anti$G$ protein antisera (Fig. 4). Both Sertoli cells and peritubular myoid cells showed immunoreactivity for all the $G$ proteins investigated (Fig. 4, A2-A5 and B2-B5). The intensity of Sertoli cell staining was greater than that seen in the myoid cells. Pachytene spermatocytes and round spermatids were not stained by anti-Gs $\alpha$ antiserum (Fig. 4, C2 and D2) but showed staining with anti-G $\beta,-\mathrm{Gi} 1 / 2$ and $-\mathrm{Gi} 3$ antisera (Fig. 4, C3-C5 and D3-D5).

\section{RNA (northern) analysis for Gsa}

The results of the immunohistochemical studies indicated that differential expression of $G$ proteins occurs in the testis. Northern blot analysis was performed on RNA from testis with a riboprobe for $G s \alpha$ to investigate whether this takes place at the transcriptional or the translational level. Northern blot analysis of total RNA probed with both antisense and sense probes for a $268 \mathrm{bp}$ segment of Gs $\alpha$ is shown (Fig. 5). Gs $\alpha$ mRNA is present from day $I$ to adult (Fig. $5 \mathrm{~A}-\mathrm{F}$ ), but a marked decrease is observed after 23 days (Fig. 5D-F). The corresponding sense probe showed no hybridization to the RNA (Fig. 5G-L). Another smaller fragment from the $3^{\prime}$ end of the Gs $\alpha$ full-length clone was used to probe the RNA, and similar results were obtained (data not shown).

\section{In situ hybridization with Gsa RNA probe}

Localization of Gs $\alpha$ RNA in different developmental stages of testis by in situ hybridization is shown (Fig. 6) as seen under 
A
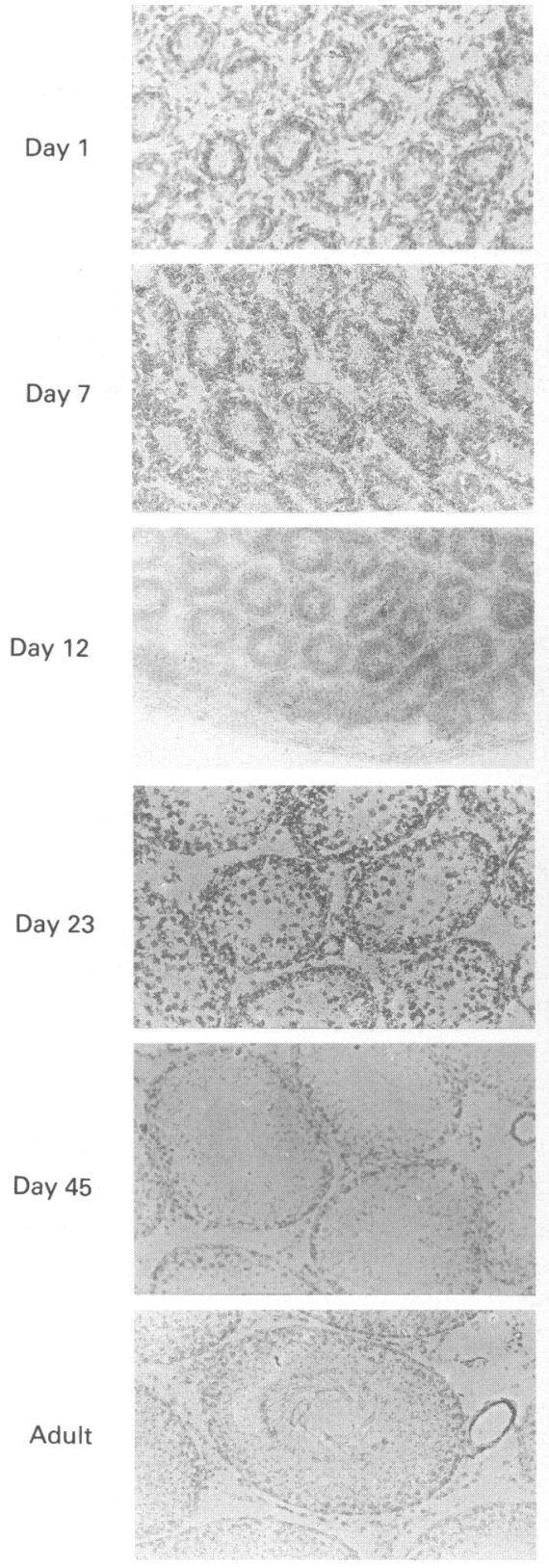
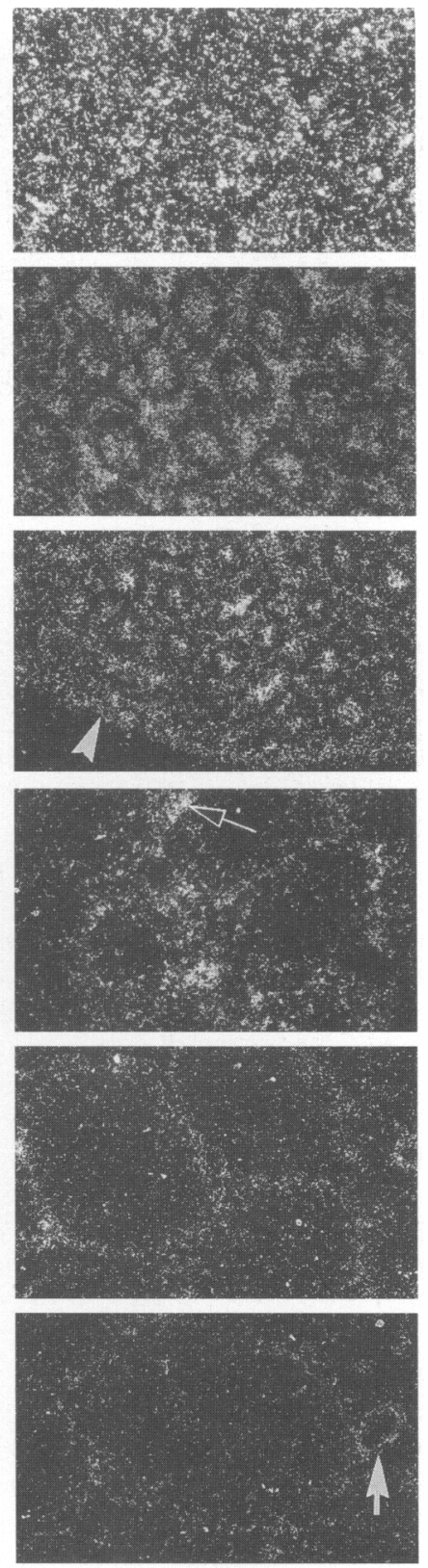

Fig. 6. Localization of the Gs $\alpha$ RNA in testes from rats at different ages by in situ hybridization. (A) Phase microscopy and (B) dark field microscopy are shown. The arrowhead at day 12 indicates the tunica albuginea. Arrows at day 23 and adult indicate the intense labelling of interstitial cells and blood vessels.

dark field microscopy and under phase microscopy. In the younger animals, day $1-12$, mRNA for Gs $\alpha$ can be seen throughout the whole testis. In 1-day-old testis, no specific pattern of hybridization is evident, but in 7-and 12-day-old testis, a pattern begins to emerge. A ring-like pattern of hybridization can be seen with transcripts located both in the centre of the tubules, possibly corresponding to the cytoplasm of the Sertoli cells, and in the interstitium. The tunica albuginea is also labelled (Fig. 6b, 12 days). At days 23 and 45 of age and in adults (60-90 days), mRNA for $G s \alpha$ appeared to be preferen- tially localized to the periphery of the tubules and very little or no hybridization was seen within the lumen. This change in localization of the mRNA parallels the morphological differentiation of cells occurring with age in the seminiferous tubule. The Sertoli and myoid cells gradually occupy a more narrow band around the periphery of the tubule, while proliferation of the spermatogonia results in an increased proportion of the tubule being occupied by the germ cells. The intensity of the hybridization signal decreased with age. Interstitial cells and blood vessels were labelled at all ages. 


\section{Discussion}

The signal transduction mechanisms regulating germ-cell differentiation remain to be elucidated; however, it is likely that the guanine nucleotide-binding proteins ( $\mathrm{G}$ proteins) are involved. Immunohistochemical studies indicated that the somatic testicular cells, as well as germ cells, express the inhibitory GTPbinding proteins, Gi1/2 and $\mathrm{Gi3}$. These results confirm previous observations (Paulssen et al., 1991), but differ in that these authors reported that pachytene spermatocytes and round spermatids were not immunoreactive for $\mathrm{Gi} 1 / 2$. However, our results are consistent with their findings that both types of cell contain significant mRNA transcripts for both subunits. In our study, germ cells were obtained from 90-day-old rats, whereas younger rats ( 30 days of age) may have been used by Paulssen and his colleagues (Paulssen et al., 1991). From our results, germ cells begin to express Gi1/2 and Gi3 between days 23 and 45 after birth, and it is possible that the discrepancy in our findings could be attributed to the fact that at day 30 , pachytene spermatocytes and round spermatids have yet to begin to express Gi1/ 2 in significant amounts. Karnik et al. (1992), in agreement with our results, also noted the presence of $\mathrm{Gi}$ proteins (Gi1, Gi2 and $\mathrm{Gi} 3$ ) in spermatogenic cells of the testes of 10-12-week-old mice. We did not study the distribution of $G$ proteins in spermatogonia because of the difficulty in obtaining purified populations of these cells in rats. Examination of cross-sections of testes, however, revealed that there was no detectable staining of spermatogonia with either $\mathrm{Gi} 1 / 2$ or $\mathrm{Gi3}$, although inhibitory $G$ proteins have been shown to be involved in growth factor-induced mitotic division in Balb/c 3T3 cells (Grouch, 1991). The physiological role of $G$ proteins in cell types that were thought to lack $G$ protein-coupled receptors led to speculations about the role of paracrine factors in the regulation of effector systems. However, a cDNA clone encoding a putative $G$ protein coupled receptor has recently been isolated from a rat testis cDNA library (Meyerhof et al., 1991). In situ hydridization experiments using a cDNA probe localized the mRNA for this novel receptor to spermatocytes and spermatids but not to somatic cells or spermatogonia (Meyerhof et al., 1991). In addition, expression of this mRNA is not seen at day 14 post partum but is first detected after day 28 and increases during the second and third months after birth. Although these observations suggest the presence of a $G$ protein-coupled receptor, for a yet unknown ligand, in different types of germ cell, a role of $G$ protein-mediated signal transduction induced by GTPaseactivating proteins (Skene, 1989) in germ cells cannot be excluded.

Although Sertoli and myoid cells could readily be stained for $\mathrm{Gi} 1 / 2$ and $\mathrm{Gi} 3$ in the isolated cells, they showed only very low levels, or no expression, in sections taken from testes of rats of corresponding age. This could be explained by the fact that, although the cells do express the protein, the levels are not high enough to be detected in cross-sections of the testis, in which there may be low cell volume (Russell et al., 1990). As expected, $G \beta$ is seen in all types of cell examined. In younger animals, the immunoreactivity is located mainly in the somatic cells and upon further development, immunoreactivity becomes evident in the cytoplasm of the germ cells at about day 23 after birth. At this time, the germ cells have yet to express the inhibitory $G$ proteins. Gs $\alpha$ was found in both Sertoli and myoid cells but not in either type of germ cell examined; this finding is consistent with the view that germ cell membranes do not contain a cholera toxin-activated G protein (Hildebrandt et al., 1985) and do not possess a hormone-sensitive adenylyl cyclase system (Haugen et al., 1990).

Gs $\alpha$ is not expressed at the protein level in testes of 1-dayold rats, despite the large amounts of transcripts produced, as shown by northern blot analysis and in situ hybridization. As we have previously shown (Dym et al., 1991), the immunostaining of Gs $\alpha$ appears to be located at the periphery of the seminiferous tubules, where the peritubular cells and the basal portion of Sertoli cells are in contact with the basement membrane (Hadley and Dym, 1987). Sertoli cell FSH receptors are found at the base of the seminiferous tubules (Orth and Christensen, 1977) and it is at this location that they are coupled to Gs $\alpha$. The apparent peak in Gs $\alpha$ production in Sertoli cells, which occurs between day 12 and day 23 , and its subsequent decrease in testes of 45-day-old and adult rats, could be attributed to the fact that Sertoli cells become insensitive to FSH stimulation via adenylyl cyclase in older animals. Several studies have shown that both in vivo and in vitro, before 20 days of age in rats, FSH increased DNA synthesis and mitotic activity (Griswold et al., 1976; Means et al., 1980). This response decreases with age and is not present in adults (Griswold et al., 1976; Means et al., 1980). Similar modulation of Gi1/2 and Gi3 in rat myometrium linked to hormonal status during gestation has been reported by Tanfin et al. (1991). Another explanation may be that there is differential expression of the two subunits of Gsa. The immunoblots showed that the antisera used in this study preferentially recognized the larger 46000 subunit, although a minor faint 42000 immunoreactive protein could also be seen. However, we have previously shown, using a different antiserum, that Sertoli cells strongly express both the 42 and $46 \mathrm{kDa}$ Gs proteins (Dym et al., 1991). To study this developmentally regulated expression of the Gs $\alpha$ protein further, we carried out northern blot analysis using total RNA from testes of rats of different ages. These studies were designed to determine whether the changes in protein concentrations were due to changes in the amount of mRNA encoding the protein. An RNA species migrating at $1.85 \mathrm{~kb}$ was noted, but the $0.9 \mathrm{~kb}$ species found in round and elongated spermatids (Gordeladze et al., 1981; Eskild et al., 1991) could not be detected. The absence of the latter may be due to the fact that total RNA from whole testis was used as opposed to RNA from individual types of cell. The results showed that there is a decrease in the amount of Gs $\alpha$ mRNA with age, but this could be due to the dilution factor of increased RNA contribution from types of germ cell that do not contain the mRNA for Gs $\alpha$ (Paulssen et al., 1991).

In situ hybridization confirmed the results obtained by RNA (northern) analyses that indicated that the $1.85 \mathrm{~kb}$ transcripts for Gs $\alpha$ were present in all the different developmental ages examined. In 1-day-old rats, the mRNA was distributed throughout the whole testis and the intensity of hybridization supported the northern blot findings that large amounts of mRNA for Gs $\alpha$ are produced. Again, comparison with the immunohistochemistry studies, in which we were unable to detect the presence of $G s \alpha$ protein, suggests that the expression of Gs $\alpha$ is regulated at the level of translation. In 7- and 12day-old testis, when the seminiferous tubules are still mainly Downloaded from Bioscientifica.com at 04/26/2023 06:12:28AM 
composed of Sertoli cells, Gs hybridization was seen in the area of the tubule corresponding to the cytoplasmic portion of the Sertoli cells. As the germ cells in the seminiferous tubule undergo differentiation, the somatic cells become more confined to the periphery of the tubule and, correspondingly, hybridization is seen around the periphery of the tubule, and in the interstitium, but is absent in the germ cells. Although in situ hybridization is not a quantitative technique, there appears to be a decrease in Gs $\alpha$ mRNA in the somatic cells with age, suggesting that some modulation at the transcriptional level may also occur. The labelling of the tunica albuginea and blood vessels confirms the presence of Gs $\alpha$ in fibroblasts and endothelial cells as well as smooth muscle (Bimbaumer ef al., 1990).

In conclusion, in the present study, we have shown differential expression of $G$ proteins in developing rat testes and it is possible that these $G$ proteins are involved in the signal transduction mechanisms regulating spermatogenesis. Both transcriptional and translational regulation appear to be involved in this process, but the precise nature of these mechanisms remains to be investigated.

The authors are grateful to L. Richardson for advice on the in situ hybridization technique and to $\mathrm{K}$. Kostrubanic for excellent technical assistance. Supported by NIH grant PO1-HD-24633.

\section{References}

Birnbaumer L, Codina J, Mattera R, Yatani A, Scherer N, Toro MJ and Brown AM (1987) Signal transduction by G proteins Kidney International 32 S14-S37

Birnbaumer L, Codina J, Yatani A, Mattera R, Graf R, Olate J, Themmen AP, Liao CF, Sanford J and Okabe K (1989) Molecular basis of regulation of ionic channels by G proteins Recent Progress in Hormone Research 45 121-208

Birnbaumer L, Abramowitz J and Brown AM (1990) Receptor-effector coupling by $G$ proteins Biochimica et Biophysica Acta 1031 163-224

Casey PJ and Gilman AG (1988) G protein involvement in receptor-effector coupling Joumal of Biological Chemistry $2632577-2580$

Chomczynski P and Sacchi N (1987) Single-step method of RNA isolation by acid guanidinium thiocyanate-phenol-chloroform extraction Analytical Biochemisiny 162 156-159

Cockcroft S and Gomperts BD (1985) Role of guanine nucleotide binding protein in the activation of polyphosphoinositide phosphodiesterase Nature $\mathbf{3 1 4}$ 534-536

Dym M, Lamsam-Casalotti S, Jia MC, Kleinman HK and Papadopoulos V (1991) Basement membrane increases G-protein levels and follicle-stimulating hormone responsiveness of Sertoli cell adenylyl cyclase activity Endocrinology 128 1 $167-1176$

Eskild W, Ree AH, Levy FO, Jahnsen T and Hansson V (1991) Cellular localization of mRNAs for the retinoic acid receptor-, cellular retinol-binding protein, and cellular retinoic acid-binding protein in rat testis: evidence for germ cell-specific mRNAs Biology of Reproduction 44 53-61

Gordeladze JO, Purvis K, Clausen OPF, Rommerts FFG and Hansson V (1981) Cellular localization of the $\mathrm{Mn}^{2+}$-dependent andenylyl cyclase $(\mathrm{AC})$ in rat testis International joumal of Andrology 4 172-182

Griswold MD, Mably ER and Fritz IB (1976) Follicle stimulating hormone stimulation of DNA synthesis in Sertoli cells in culture Molecular and Cellular Endocrinology 4 139-149
Grouch MF (1991) Growth factor induced cell division is paralleled by translocation of Gi $\alpha$ to the nucleus FASEB Joumal 5 200-206

Hadley MA and Dym M (1987) Immunocytochemistry of extracellular matrix in the lamina propria of the rat testis: electron microscopic localization Biology of Reproduction 37 1283-1289

Hadley MA, Byers SW, Suarez-Quian CA, Kleinman HK and Dym M (1985) Extracellular matrix regulates Sertoli cell differentiation, testicular cord formation, and germ cell development in vitro Journal of Cell Biology 101 1511-1522

Haugen TB, Paulssen EJ, Gardeladze JO and Hansson V (1990) A unique mRNA species for the $\alpha$ subunit of $G$ s is present in rat haploid germ cells Biochemical and Biophysical Research Communications 168 9I-98

Hildebrandt JD, Codina J, Tash JS, Klrchick HJ, Lipschultz L and Sekura RD (1985) The membrane-bound spermatozoal adenylyl cyclase system does not share coupling characteristics with somatic cell adenylyl cyclase Endocrinology $1161357-1366$

Jelsema CL and Axelrod J (1987) Stimulation of phospholipase A2 activity in bovine rod outer segments by the beta gamma subunits of transducin and its inhibition by the alpha subunit Proceedings of the National Academy of Sciences USA 84 3623-3627

Jones DT and Reed RR (1987) Molecular cloning of five GTP-binding protein cDNA species from rat olfactory neuroepithelium journal of Biological Chemistry $26214241-14249$

Karnik SN, Newman S, Kopf GS and Gerton GL (1992) Developmental expression of $\mathrm{G}$ protein $\alpha$ subunits in mouse spermatogenic cells: evidence that $\mathrm{G} a \mathrm{i}$ is associated with the developing acrosome Developmental Biology 152 393-402

Laemmli UK (1970) Cleavage of structural protein during the assembly of the head of bacteriophage T4 Nature 227 680-685

Means AR, Dedman JR, Tash JS, Tindall DJ, van Sickle M and Welsh MJ (1980) Regulation of the testis Sertoli cells by follicle stimulating hormone Annual Review of Physiology 42 59-70

Meyerhof W, Muller-Brechlin R and Richter D (1991) Molecular cloning of a novel putative G-protein coupled receptor expressed during rat spermiogenesis FEBS Letters 284 155-160

Onoda M and Djakiew D (1991) Pachytene spermatocyte protein(s) stimulate Sertoli cells grown in bicameral chambers: dose dependent secretion of ceruloplasmin, sulfated glycoprotein- 1 , sulfated glycoprotein-2 and transferrin In Vitro Cellular and Developmental Biology 27 215-222

Orth J and Christensen AK (1977) Localization of ${ }^{125}$ I-labeled FSH in the testes of hypophysectomized rats by autoradiograph Endocrinology $101262-278$

Parvinen M, Vihko KK and Toppari J (1986) Cell interactions during the seminiferous epithelial cycle International Review of Cytology 104 115-151

Paulssen RH, Paulssen EJ, Gordeladze O, Hansson V and Haugen TB (1991) Cellspecific expression of guanine nucleotide-binding proteins in rat testicular cells Biology of Reproduction 45 566-571

Platts EA Schulster D and Cooke BA (1988) The inhibitory GTP-binding protein (Gi) occurs in rat Leydig cells and is differentially modified by luteotropin and 12-0-tetradecanoylphorbol 13-acetate Biochemistry 253 895-899

Richardson LL, Chan WY and Dym M (1991) Localization of pregnancyspecific $\beta 1$-glycoprotein in the male reproductive tract of the rat by in situ hybridization Biology of Reproduction 45 704-710

Russell LD, Ren HP, Sinha Hikim I, Schulze W and Sinha Hikim AP (1990) A comparative study in twelve mammalian species of volume densities, volumes, and numerical densities of selected testis components, emphasizing those related to Sertoli cell American Journal of Anatomy 188 21-30

Sandberg M and Vuorio E (1987) Localization of types I, II and III collagen mRNAs in developing human skeletal tissues by in situ hybridization joumal of Cell Biology 104 1077-1084

Skene JHP (1989) Axonal growth-associated proteins Annual Review of Neuroscience 12 127-156

Tanfin Z, Goureau O, Milligan G and Harbon S (1991) Characterization of G proteins in rat myometrium. A differential modulation of $\mathrm{Gi} 2 \alpha$ and $\mathrm{Gi} 3 \alpha$ during gestation FEBS Letters $\mathbf{2 7 8} 4-8$ 